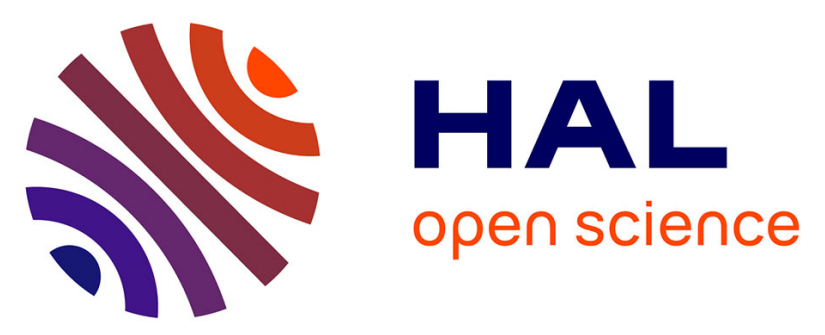

\title{
Towards a Model of Corporate and Social Stakeholder Engagement: Analyzing the Relations Between a French Mutual Bank and Its Members
}

Carine Girard, André Sobczak

\section{- To cite this version:}

Carine Girard, André Sobczak. Towards a Model of Corporate and Social Stakeholder Engagement: Analyzing the Relations Between a French Mutual Bank and Its Members. Journal of Business Ethics, 2012, 107 (2), pp.215-225. 10.1007/s10551-011-1034-3 . hal-00813154

HAL Id: hal-00813154

https://hal-audencia.archives-ouvertes.fr/hal-00813154

Submitted on 15 Jul 2013

HAL is a multi-disciplinary open access archive for the deposit and dissemination of scientific research documents, whether they are published or not. The documents may come from teaching and research institutions in France or abroad, or from public or private research centers.
L'archive ouverte pluridisciplinaire HAL, est destinée au dépôt et à la diffusion de documents scientifiques de niveau recherche, publiés ou non, émanant des établissements d'enseignement et de recherche français ou étrangers, des laboratoires publics ou privés. 


\title{
Towards a Model of Corporate and Social Stakeholder Engagement: Analyzing the Relations Between a French Mutual Bank and Its Members
}

\author{
Carine Girard and André Sobczak
}

\section{Introduction}

A growing number of businesses from all sectors and sizes is seeking to improve the impact of their activity on the economic, social, and natural environment. Many are undertaking projects, some of which are ambitious, to contribute to the economic development of their region, the reduction of social injustices or the protection of the environment. Some have integrated the principles of corporate social responsibility (CSR) into their strategy, engaging a learning process with their various stakeholders to improve their impact on the economic, social, and natural environment (Berthoin Antal and Sobczak 2004). The legitimacy and efficiency of these projects largely depend on the quality of the relationship the company is able to build with its stakeholders and particularly on its ability to create a relationship of trust, allowing common goals to be established and the changes necessary to achieve these goals to be implemented. What is important is not only the content of the practices implemented, but also the way in which they are developed and established, a process shared with stakeholders being increasingly preferred to decisions made by managers alone.

In view of this, the management's first steps towards a CSR policy consist in identifying the different stakeholders of their business and their representatives and analyzing their interests and expectations in relation to the business. Over the last 30 years, much management research has consequently focused on the methods of analyzing and mapping stakeholders and their interests, as well as the way the business managers may handle their relationships with them (Stieb 2009; Bevan and Werhane 2011). This article builds on this research, but aims to go further, by demonstrating the value of establishing a dynamic profile of stakeholders, which aims to classify them according to their engagement to the company, called hereafter corporate engagement, and to the natural and social environment, called hereafter social engagement. After presenting the principles of this new mapping, we will demonstrate its value through an initial business case study where it was tested.

In the second section, we present our new stakeholder mapping, which aims to establish a dynamic profile of a company's stakeholders based on their corporate and social engagement. After a review of the literature on the analysis and management of stakeholders, this second section will demonstrate the limitations of the main mappings currently used in this area and then propose a new, more dynamic conceptualized model. In the third section, we highlight the benefits of this new mapping and its use, based on a study aimed at analyzing the interests and expectations of the members of a French mutual bank in terms of CSR. We then present the methodology of this study and its primary results before concluding with the lessons to be drawn from this first test of a dynamic mapping of stakeholders based on engagement.

The choice of this case study has two interesting aspects. On the one hand, the members of mutual banks are difficult to categorize in the most commonly used stakeholder mappings, as they are both shareholders and clients, and sometimes even bank employees, which confirms the usefulness of a new mapping system that transcends these categories. On the other hand, little management research to date has involved the mutual and cooperative sector, even in the area of CSR. However, the unique governance of the cooperative sector affords a model, which may lend itself to a better integration of the economic, social, and environmental issues at stake than that of businesses in the free market sector. 


\section{A New Stakeholder Mapping}

Beginning with a review of the literature on stakeholder analysis and management, in this first section, we seek to show the limitations of the current mappings being used in this area with the goal of proposing a new, dynamic stakeholder mapping based on stakeholder engagement to the company and on the principles and values of CSR.

\section{Developing Engaged Stakeholders}

According to the most commonly used definition, the stakeholders of an organization are the individuals and groups, which affect or are affected by the achievement of its objectives (Freeman 1984). Some authors emphasize the fact that these individuals or groups contribute, either voluntarily or involuntarily, to its wealth-creating capacity and activities, and are therefore its beneficiaries and/or risk bearers (Post et al. 2002). In general, these definitions are illustrated by a non-exhaustive list of a company's stakeholders, which usually includes employees, shareholders, clients, suppliers, local authorities, and NGOs. To implement a CSR strategy, managers must begin by identifying the company's various stakeholders (Freeman and Gilbert 1987), their respective expectations of the company along with their strategies (Freeman 1999). The success of a CSR strategy will then depend on in-depth analysis of the advantages and influences of these things (Wood 1994). Research carried out in this area shows that the different members of each category of stakeholders do not comprise a uniform group (Wolfe and Putler 2002) and do not necessarily have the same goals concerning a company (Wood 1994; Scholes and Clutterbuck 1998), which makes a classification of the members of the different stakeholder groups essential (Freeman and Gilbert 1987).

The best known classification is one which distinguishes between, on the one hand, primary or contractual stakeholders, including shareholders, employees, clients and suppliers and, on the other hand, secondary stakeholders such as for example NGOs, local authorities, media, or competitors (Caroll 1989; Donaldson and Preston 1995). Other authors (Mitchell et al. 1997) propose a classification of stakeholders according to their power of influence, their degree of legitimacy and the urgency of their claim on the organization. These classifications, which are complementary rather than distinct, share an interest in the nature of the relationship a company has with its stakeholders, without going so far as to integrate the element of commitment, although this occupies an increasingly important place in research on company/ stakeholder relations.

Much research aims to outline principles for stakeholder management (Freeman and Mc Vea 2001). One might ask if the term 'management' and the concept it represents is appropriate for a company's relationships with its stakeholders. Harrison and St. John (1996) suggest speaking rather of partnership activities, which allow companies to build bridges with their stakeholders in the pursuit of common goals, whereas the traditional stakeholder management techniques only allow for the fulfilment of stakeholders' needs and expectations. Some companies even go beyond partnership with their stakeholders and seek to engage them in a learning process for CSR (Berthoin Antal and Sobczak 2004).

This idea is confirmed by recent literature on stakeholder engagement. Greenwood (2007) argues that this emerging concept is an under-theorized area. Her research (2007) suggests taking two aspects into account when analyzing business practices with regard to their stakeholders: firstly, the moral aspect and accounting for the number of beneficiaries or creditors whose interests are considered by the company; secondly, the stakeholders' engagement, which measures the quality of the consultation, communication, and dialoguing processes which allow stakeholders to have some influence. In this way, the company must not only seek to satisfy its stakeholders and avoid conflicts of interests, but also engage them in a process of continual and constructive dialog.

According to Maak (2007), the benefits of such an engagement are mutual. If stakeholders find that some of their expectations are being met, the company benefits from the social capital that the stakeholders invest, which corresponds to "the aggregate of the actual or potential resources which 
are linked to possession of a durable network of more or less institutionalized relationships of mutual acquaintance and recognition" (Bourdieu 1980). The company can mobilize these resources to create and distribute information, knowledge, and trust by intentionally bringing together committed parties, thus contributing to the firm's CSR strategy. This type of stakeholder engagement can therefore be considered a learning process, described as the link between a company and its stakeholders, leading the latter to believe in the norms, values, and objectives of the company, to be active on its behalf and to desire to maintain a relationship with it, whatever form that relationship may take. The significance of this notion of engagement, developed in the field of cognitive and social psychology, leads us to include it in the new stakeholder mapping system, which we propose. However, basing stakeholder profiles on this engagement alone would lead to the exclusion of other aspects. Indeed, Greenwood (2007) specifies that stakeholder engagement does not necessarily contribute to CSR insofar as 'irresponsible' stakeholders may be involved, who are not really concerned about the economic, social, or natural environment.

Sloan's (2009) recent review of the stakeholder engagement literature suggests that there are two dimensions of stakeholder engagement. The first one is characterized by communications and monitoring activities aimed at controlling and managing risks related to conflicts of interests. The second one is made up of collaborative activities such as communications, collaborations, and partnerships to generate strong social performance.

Let us take the example of 'active' shareholders to illustrate our point. According to Logsdon and Van Buren III (2009), these shareholders play a dual role. As primary stakeholders, they act as traditional investors, hoping for a good return on their investment of financial capital. As secondary stakeholders, they act as activists. Their role is disciplinary and aims to align their financial interests with those of management. This corporate engagement may take on varying forms. The 'private engagement' is exercised behind the scenes and is characterized by informal meetings with the management. The second form called 'public engagement' is mediatized. It aims at improving environmental, social, governance and performance-related issues thanks to a more confrontational dialog using the resolution process at AGM. In parallel of these two disciplinary activities, certain shareholders mobilize their social capital to further the company's practices towards CSR in a longterm perspective. According to Logsdon and Van Buren III, they act in this way as secondary stakeholders, mobilizing their relational investing. These relational investors are increasingly aware that it is in their long-term interest to engage with management rather than simply to sell their shares (Hawley and Williams 2007; Bhagat et al. 2004). They realize that their impact is magnified when they coordinate their actions as a rapidly rising form of socially driven shareholder activism via collaborative coalitions and networks demonstrates (Thamotheram and Wildsmith 2007). For Thamotheram and Wildsmith (2007), these stakeholders are in 'learning-by-doing process' in constructing new norms (MacLeod 2009). According to Sloan's models of stakeholder engagement (2009, p. 38), an inclusive engagement approach is needed to favor dialog whereby companies can modify their perceptions of stakeholders from being a source of risks to a source of opportunity.

This review of the literature suggests two different forms of engagement: corporate engagement and social engagement. We suggest a new stakeholder mapping based on these two kinds of engagement that may be applied to all stakeholders.

\section{Conceptual Model of Stakeholder Engagement Levels}

According to the previous review of the stakeholder literature, engagement could be defined as a learning process characterized by the creation and diffusion of trust, knowledge, and values, to build a foundation of social capital. Employees' corporate engagement has been the subject of much research in human resource management and CSR (Turker 2009). The literature in this area distinguishes between different aspects and different goals of engagement designed as organizational commitment. Meyer and Allen $(1991,1997)$ bring out three aspects of organizational commitment: affective, normative, and continuance commitment. Affective commitment is characterized by an emotional attachment to the organization. The employee stays with the 
organization because he wants to. Normative commitment, however, stems from a sense of moral obligation. As explained by Greenwood (2007), the notion of engagement always incorporates a moral dimension. In this case, the employee stays with the organization because he thinks he should. Lastly, continuance commitment - henceforth referred to as calculated commitment -is linked to a realization of the cost involved in leaving the organization. The employee stays with the organization because he needs to. Affective, normative, and calculated commitment should be considered as different aspects of corporate engagement rather than different sorts of commitment. Indeed, these aspects are not mutually exclusive, and an employee's commitment may include all three to varying degrees. An employee may therefore feel a strong desire and a great need to stay with the organization (Meyer and Allen 1991).

The idea of organizational commitment may also be transposed to other stakeholder groups, at least the primary ones, such as shareholders, clients, and suppliers. Even if organizational commitment translates differently into each category, these parties may actually want to stay in contact with the company, simply feel obliged to, or do so in a calculated manner. This is particularly true of shareholders for whom we can distinguish the same three aspects of commitment as identified for employees. For example, in companies undergoing financial difficulty, normative commitment manifests itself through the support of shareholders who feel obliged to maintain their financial participation (Lemoine and Onne'e 2001). In this case, dissatisfied shareholders do not exert their exit rights but rather their loyalty and voting rights to dialog with the corporation. Affective commitment implies that the shareholder identifies with the company he has invested in, which can be seen by shareholders' presence on consultation committees, in shareholders' clubs or societies, at stock exchange training seminars, on visits to business sites or cultural exhibitions. However, we emphasize the fact that affective and normative commitments do not usually come about unless the company also maintains calculated commitment corresponding to acceptable financial results.

The three aspects brought out in the area of organizational commitment can also be transposed to social engagement. Indeed, affective attachment, a feeling of moral obligation or calculated reasoning may explain activities aiming at improving the impact on the economic, social, and natural environment. The stakeholders can therefore support a CSR policy because they want to, because they feel obliged to, or because they think it is necessary.

By evaluating both types of engagement for the different stakeholders of a company, we can establish a new segmentation, based on a distribution graph with two axes, one measuring corporate engagement and the other measuring social engagement (Fig. 1). This segmentation shows four profiles taken from a company's stakeholders. The first group is characterized by both a weak level of corporate and social engagement. Described as 'passive stakeholders', the members of this stakeholder group will have difficulty being involved in a CSR strategy without some input from management. A second group on the other hand, shows both a high level of corporate engagement and a high level of social engagement. The members of this group, which we will call 'engaged stakeholders', are key players for the management and even the driving force behind the CSR policy. The other two groups show an imbalance between the two types of commitment. The 'allied stakeholders' have a high level of corporate engagement, but a low level of social engagement, whereas it is the other way around for the 'militant stakeholders'. Managers could act to move the members of the different groups towards the 'engaged stakeholders' group. Corporate engagement as well as social engagement may indeed be developed through management practices.

Of course, the corporate and social engagement may evolve, thus creating a need for a dynamic approach to this mapping system. If this exercise is renewed on a regular basis, one can measure the evolution of stakeholders' engagement and the impact of the managers' practices on corporate and social engagement, the aim being potentially to move the different categories of stakeholders to the category of engaged stakeholders. 


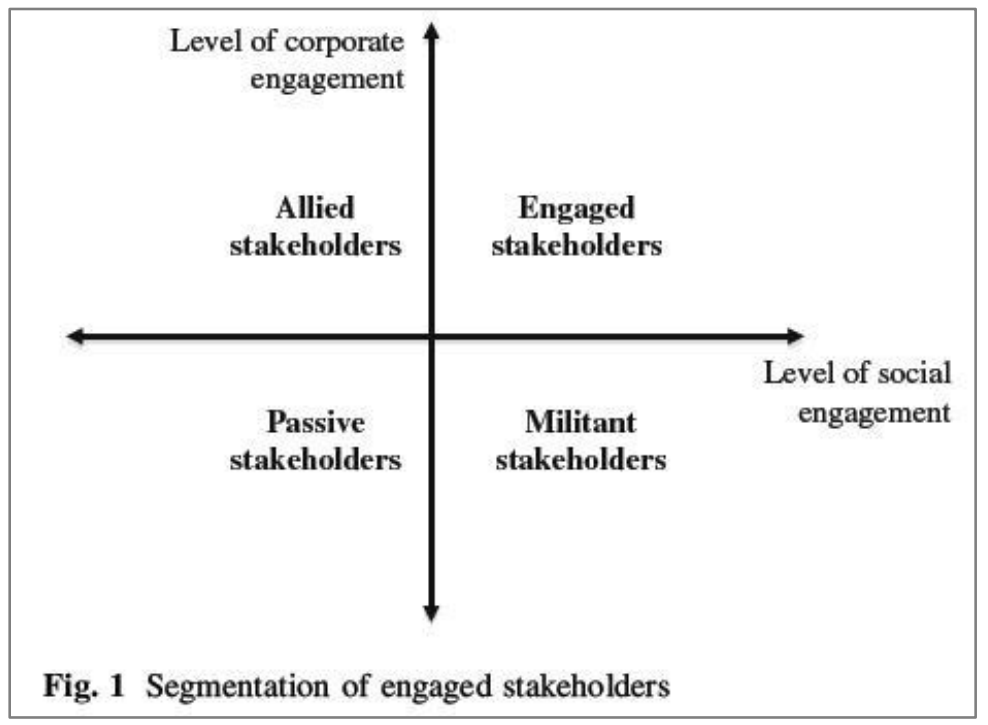

\section{A Segmentation of the Members of a French Mutual Bank}

In order to test this new stakeholder mapping, we carried out an initial study on a unique group of stakeholders of a business, which is itself quite unique: the members of a regional mutual bank in Western France: Banque Populaire Atlantique (BPA). The members of a mutual bank as a group of stakeholders make an interesting case study for testing our conceptual model, because they simultaneously possess two, sometimes even three legal statuses. They are both shareholders and clients of the bank and may also be bank employees. Unlike shareholders of a listed bank corporation, they have no right to the bank's reserves, and do not collect any 'financial dividends', but rather a 'cooperative dividend' $1^{1}$ of which a portion is placed towards a strategy for CSR. A member can therefore not only fit within three groups of primary stakeholders (shareholders, clients, or employees), but may also play the role of an active secondary stakeholder defending a social and/or environmental cause. In order to analyze members' interests and expectations, it seems important therefore to create a more precise segmentation, such as our stakeholder mapping model based on corporate and social engagement.

Our study was carried out on the BPA, which has been committed for several years to CSR, mainly through integrating economic, social, and environmental issues into its mid-term strategic plan. To continue to improve their strategy, the bank managers seek to develop the commitment of their stakeholders, and particularly of their members. In order to determine the action to take towards this initiative, we carried out a qualitative study which initially aimed to segment the different members of the BPA according to their corporate and social engagement.

The value of this study goes beyond the structure of the BPA and contributes to the questions that mutual bank managers are asking themselves about how to improve relations with their members and how to better involve them in the banks' development. Generally, French mutual banks are facing a decline in their membership, which is shown both by a decrease in the number of members and by a declining involvement in governance, both of which are linked to developments in law, in society and in industry competition (Richez-Battesti 2006). To begin with, members were typically uniformly socio-professional, which led to a certain level of corporate commitment and common interests. Today, the members of these banks include several quite diverse socio-professional groups and would only seem to be united by a certain number of common values. Indeed, communication initiatives on the part of the mutual banks about their strategies for CSR, which are founded on

\footnotetext{
${ }_{1}^{1}$ Cf. Study "60 million members in co-operative banks: What does it mean?" carried out in 2006 by the European Association of Cooperative Banks.
} 
mutual and corporate values (Chiffet 2006), aim to strengthen this base of common values. Nevertheless, this communication often proves insufficient and can generate new risks linked to issues surrounding the legitimacy of their governance. Hence, one of the current issues for mutual banks is to increase membership numbers significantly and strengthen members' engagement by moving them from a passive status to a more active one.

\section{Methodology}

In order to make our stakeholder segmentation model operational, we decided to submit an on-line survey to a sample of BPA members. The goal was to create a scale of stakeholders' corporate and social engagement. For corporate engagement we chose to use as a basis Meyer and Allen's scale (1991), which measures the three aspects of employees' organizational commitment, and adapt it to the members of a mutual bank. We reformulated thus the questions designed for employees having a contract of employment to take into account the specific relations between members having bought shares from a mutual bank, trying to be as close as possible to the initial questions. For example, we replaced the item "I could just as easily have become an employee of another company" by "I could just as easily have become a member or shareholder of another bank".

For social engagement, no similar scale existed, and we thus had to create a specific one. To do this, we questioned a sample of members from BPA about concrete behaviors that reflected for them an awareness of social and environmental issues. Our aim was to be as close as possible to their perceptions of social commitment, taking into account the national and local contexts as well as the sociological composition of the members of BPA. During the first stage, we created two focus groups, in December 2007 and January 2008, each time bringing together 20 members of different ages and socio-professional groups. These members are all clients and shareholders. In the second stage, we tested our survey on 72 students who had chosen to follow courses specifically dealing with CSR in a school of management.

The survey has four sections, the two first ones being included as appendix. In the first section "You as a member of society" (questions 1-10), 10 items gage members' social engagement. Second section called "You as a member of the Banque Populaire Atlantique" (questions 11-27), gages members' corporate engagement to the BPA. In questions 11-16, we see Meyer and Allen's items for measuring affective commitment. Questions 17-19, 26 and 27 measure the aspect of normative commitment. Lastly, questions 20-25 measure the final aspect, that of calculated commitment. Third section measured the 'knowledge about BPA's CSR policies'. Fourth section is the respondent's answer form.

The survey was written using the site: http://freeonline surveys.com and sent via email to the 2000 BPA members with an Internet connection, out of a total of 100,022 members. These members are all clients and shareholders. In all, 382 surveys were completed (corresponding to a $17.36 \%$ response rate).

The respondent profile outlined in Box 1 is quite close to that of all BPA members in terms of sex, age, socioprofessional groups, and seniority. 


\section{Results}

Overall survey results show relatively weak corporate engagement of BPA members. That is, 287 out of 382 members (75.1\%) replied that they do not attend BPA Annual General Meetings. These results are not specific to the BPA. Other studies have shown that the number of members attending mutual and cooperative company AGMs is between 10 and 30\% (Sibieude and Vidal 2008).

\begin{tabular}{|c|c|}
\hline Men & 239 members ( $62.6 \%$ of population) \\
\hline Women & 143 members ( $37.4 \%$ of population) \\
\hline Total & 382 members \\
\hline \multirow[t]{3}{*}{ Age: } & 42 members surveyed: under 30 years ( $11 \%$ of population) \\
\hline & 229 members surveyed: $31-60$ years ( $59.9 \%$ of population) \\
\hline & 111 members surveyed: over 60 years ( $29.1 \%$ of population) \\
\hline \multicolumn{2}{|c|}{$\begin{array}{l}\text { Socio-professional group: less than a third of members are retired }(30.1 \% \text { of population). Most members are bank of ficers ( } 26.2 \% \text { of population) } \\
\text { and employees }(24.6 \% \text { of population) }\end{array}$} \\
\hline \multicolumn{2}{|c|}{$\begin{array}{l}\text { Over a third of respondents ( } 39.3 \% \text { of population) have been BPA members for less than } 5 \text { years and under a third ( } 27 \% \text { of population) has been } \\
\text { BPA members for at least } 25 \text { years }\end{array}$} \\
\hline
\end{tabular}

However, the study does demonstrate members' social engagement. Indeed, 133 members $(34.82 \%$ of the population) are active members of organizations or involved in the public sphere. Of course, this level corresponds to the national level of involvement in an organization in France (34\%: INSEE2) $)^{2}$, but the engagement we are measuring only concerns engagement within humanitarian, charitable or environmental organizations, whereas the calculated level also includes people involved in other organizations, such as sports clubs (14\% of the French population). Social engagement of BPA members can also be seen in their interest in investing responsibly. Indeed, 105 members ( $27.49 \%$ of the population) stated that they consider social and environmental factors in savings and investment decisions.

Our goal over and above these general results was a segmentation of BPA members according to their corporate and social engagement levels. A principle component analysis (PCA) enabled us to identify four groups of members that differ with regards to their corporate and social commitment levels. Each group has specific behaviors that may request the BPA managers to develop specific tools to develop their engagement levels.

\section{Identification of the Independent Composite Variables}

To this end, the first 27 items were initially subjected to PCA to identify the independent composite variables. The goal was to check whether, among these variables, we would find both the corporate engagement and social engagement variables. This analysis of the 27 variables initially chosen, allowed us to isolate seven factors presented in Table 1 . These factors account for $56.39 \%$ of the information with a KMO of 0.842 .

The first factor identified by the PCA relates to corporate engagement. It accounts for $21.57 \%$ of the total information and includes 15 of the 18 items covering the three aspects of corporate engagement. Several items measuring normative commitment come first; item 18, 'proud to tell others I a BPA member' (0.704) in our survey (Appendix 1), followed by item 23, 'loyal to the BPA

\footnotetext{
${ }_{2}^{2}$ Membership rates of different organisations (online). 2006. Available on the INSEE website: http://www.insee.fr/fr/themes/tableau. asp?reg_id=0\&ref_id=NATSOS05512\%C2 (found November 10, 2009).
} 
because very involved', (be it economically, emotionally, or socially) and item 17, 'loyal to the BPA because we share the same values' (0.682). Next, we see one of the first items (number 11 in the survey) to measure the aspect of affective commitment that of being 'pleased to be a member' (0.670). Conversely, we see that the lack of affective commitment correlates negatively to this PCA. So item 14, 'indifferent to whether a member of the BPA or another bank' (-0.403), item 15, 'do not feel like a member' (-0.503) and item 16, 'no engagement to the BPA' (-0.518) are negatively correlated to this PCA. We also see that some items measuring the aspect of calculated commitment are positively or negatively correlated to this CPA. This is true of item 20, 'difficulty leaving the BPA even if I wanted to' (0.550).

The second factor, which accounts for $10.23 \%$ of the total information, corresponds to social engagement. In fact, this PCA comprises seven of the eleven items measuring members' social engagement. The items most strongly correlated to this axis are item 2, 'organically grown produce' (0.656), item 1, 'fair-trade' (0.625), item 4, 'local produce' (0.569) and item 7, 'financial giving' (0.566). We can see that this axis has a weak positive correlation to both other environmental items found on the last factorial axis. This is backed up by a recent study by Sibieude and Vidal (2008) which shows that one of the characteristics of membership in France is social engagement stemming from regionally based mutual or cooperative groups.

The following three factors comprise one of the three non-constituent aspects of corporate engagement of the first PCA. Cumulatively, these three axes account for $16.64 \%$ of the total information. The third factor accounts for $6.36 \%$ of the total information and measures the 'lack of affective commitment'. Item 21, 'plan on leaving the BPA due to lack of involvement' (0.512), is positively correlated to this factor. The fourth factor accounts for $5.32 \%$ of the total information and measures some aspects of the lack of normative commitment. Item 27 , 'would feel guilty leaving the BPA' (-0.511), and item 19, 'worried about investment-related loss' are negatively correlated to this factor. We would therefore describe this factor as a lack of normative commitment. 


\begin{tabular}{|c|c|c|c|}
\hline \multirow[t]{32}{*}{$\begin{array}{l}\text { Table } 1 \text { Component analysis } \\
\text { of items regarding corporate and } \\
\text { social engagement }\end{array}$} & Factors & Characteristics & $\begin{array}{l}\text { Linear } \\
\text { correlation } \\
\text { coefficient }\end{array}$ \\
\hline & Corporate engagement & Proud to tell others I am a BPA member & 0.704 \\
\hline & & $\begin{array}{l}\text { Loyal to the BPA because I am very } \\
\text { involved }\end{array}$ & 0.682 \\
\hline & & $\begin{array}{l}\text { Loyal to the BPA because we share the } \\
\text { same values }\end{array}$ & 0.682 \\
\hline & & Pleased to be a member & 0.670 \\
\hline & & Enjoy talking about the BPA & 0.639 \\
\hline & & Concerned by the BPA's problems & 0.591 \\
\hline & & $\begin{array}{l}\text { Even if disadvantaged, I would remain a } \\
\text { BPA member }\end{array}$ & 0.579 \\
\hline & & $\begin{array}{l}\text { Difficulty leaving the BPA even if I } \\
\text { wanted to }\end{array}$ & 0.550 \\
\hline & & $\begin{array}{l}\text { Would feel guilty if I had to leave the } \\
\text { BPA }\end{array}$ & 0.529 \\
\hline & & $\begin{array}{l}\text { I have stayed with the BPA due to lack of } \\
\text { other opportunities }\end{array}$ & 0.480 \\
\hline & & No engagement to the BPA & -0.518 \\
\hline & & Do not feel like a member of the BPA & -0.503 \\
\hline & & $\begin{array}{l}\text { Easy to leave the BPA because not too } \\
\text { involved }\end{array}$ & -0.423 \\
\hline & & $\begin{array}{l}\text { Indifferent to whether a member of the } \\
\text { BPA or another bank }\end{array}$ & -0.403 \\
\hline & Social engagement & Organic agriculture & 0.656 \\
\hline & & Fair trade & 0.625 \\
\hline & & Local produce & 0.569 \\
\hline & & Financial giving & 0.566 \\
\hline & & Seasonal fruit and vegetables & 0.499 \\
\hline & & $\begin{array}{l}\text { Active member in an organization or } \\
\text { public sphere }\end{array}$ & 0.457 \\
\hline & & $\begin{array}{l}\text { Consider social and environmental factors } \\
\text { in savings and investment choices }\end{array}$ & 0.457 \\
\hline & $\begin{array}{l}\text { Lack of affective } \\
\text { commitment }\end{array}$ & $\begin{array}{l}\text { Plan on leaving the BPA because not very } \\
\text { involved }\end{array}$ & 0.512 \\
\hline & & No obligation to remain a BPA member & 0.461 \\
\hline & $\begin{array}{l}\text { Lack of normative } \\
\text { commitment }\end{array}$ & $\begin{array}{l}\text { Even to my disadvantage I would remain } \\
\text { a member }\end{array}$ & -0.457 \\
\hline & & $\begin{array}{l}\text { Would feel guilty if I had to leave the } \\
\text { BPA }\end{array}$ & -0.511 \\
\hline & Calculated commitment & Too costly to leave the BPA & 0.647 \\
\hline & & Worried about investment-related loss & 0.413 \\
\hline & Lack of social engagement & Public transport or car-pooling & -0.463 \\
\hline & & $\begin{array}{l}\text { Active member of an organization and/or } \\
\text { the public sphere }\end{array}$ & -0.415 \\
\hline & Environmental engagement & Recycle my rubbish & 0.556 \\
\hline & & Public transport or car-pooling & 0.439 \\
\hline
\end{tabular}

Finally, the last two factors account for two aspects of social engagement which are not taken into account in the second factor. The fifth factor accounts for only $4.2 \%$ of the total information and has a weak negative correlation with two items: one measuring environmental engagement, by the member's use of 'public transport or car-pooling' (item 6, with a correlation coefficient of -0.463) and the other measuring the social activism of this same member, by his active participation in an organization or the public sphere (item 8, with a linear correlation coefficient of -0.415). This axis serves to measure the 'lack of social engagement'. The sixth factor accounts for $3.75 \%$ of the total information. Unlike the previous instance, environmental issues are positively correlated to this factor. So item 5 , 'I recycle my rubbish', has a positive correlation with this axis $(0.556)$ as does item 
6, 'public transport or car-pooling' (0.439). This axis serves to measure one of the aspects of social commitment, which we will describe as environmental engagement.

Description of the Four Groups of Members Subsequently, based on the factorial scores, a segmentation of BPA members was made using the 'dynamic cloud' cluster analysis. This method allows us to highlight four relatively homogenous groups of members. Table 2 shows the averages of the seven factors by member group.

The members of group 3 (a total of 126 , or $28.9 \%$ ) are highly engaged to BPA (0.63) and rather engaged to the social and natural environment (0.13). They seem to correspond to the group of engaged stakeholders, but the engagement to the principles of CSR remains quite low and is even negative for the social dimension. The members of this group are much more informed about BPA's activities in the field of CSR, such as the integration of handicapped workers and the offer in the field of socially responsible investment. This may be easily explained by their corporate engagement, which makes them more attentive to the bank's different communications in this field. However, within this group, older members and those who have a long-term relationship with BPA are underrepresented. This seems to indicate that BPA has some difficulties in maintaining a high level of commitment of its members over time and thus confirms the perception of the bank's management team as well as a general challenge for mutual banks in France.

The members of group 2 (a total of 107 , or $28.1 \%$ of all respondents) are strongly engaged to the natural and social environment $(-0.74)$, but are negatively engaged to the organization $(-0.87)$. They correspond to the group of militant stakeholders. The members of this group are much less aware about BPA's different activities in the field of CSR, be it the integration of handicapped workers or the offer of socially responsible investment products for the clients. This finding highlights a close link between the low level of corporate engagement and the lack of knowledge on the bank's CSR strategy. On the one hand, the low corporate engagement may explain this lack of knowledge. On the other hand, the lack of knowledge may prevent higher corporate engagement. BPA's managers should thus improve their communication about the bank's CSR activities towards this group, in which members in the ages of 40-60 and those having been members for between 10 and 25 years are strongly over-represented.

The members of group 4 (a total of 73 , or $19.2 \%$ of all respondents) are weakly engaged to BPA (0.18), but show a strongly negative engagement to the natural and social environment $(-0.79)$. This group corresponds to the allied stakeholders. Their awareness of BPA's different CSR activities is close to the average of the total sample of respondents. In a similar way, the age structure of this group and the number of years they have been members of BPA is close to the average of the sample.

Finally, the members of group 1 (a total of 91 , or $24.88 \%$ of all respondents) are quite similar to the previous one in terms of commitment to BPA (0.10). However, this engagement is mostly due to a calculated commitment to the bank. As to the natural and social environment, it remains negative (0.40 ), but less than in the previous group. Even if they may formally be considered as allied stakeholders, their engagement is calculated. Their interest in BPA seems to be limited to the traditional disciplinary relation between a bank and its clients or shareholders. On the contrary, they are not interested in the bank's activities. They may thus form a sub-group that has the characteristics of what Fasterling (2008) calls 'detached' stakeholders. As for the previous group, their awareness of BPA's different CSR activities is close to the average of the entire sample of respondents. However, within this group, the members under 40 years are over-represented. This seems to indicate that, even if they are not necessarily engaged towards the natural and social environment, the younger generations are less reluctant to the integration of these issues by their bank. BPA's managers may thus start to develop a communication on their CSR activities targeted to the younger generations. 


\begin{tabular}{|c|c|c|c|c|}
\hline $\begin{array}{l}\text { Four groups of members } \\
\text { Number of members per group }\end{array}$ & $\begin{array}{l}1 \\
N=91\end{array}$ & $\begin{array}{l}2 \\
N=107\end{array}$ & $\begin{array}{l}3 \\
N=110\end{array}$ & $\stackrel{4}{N}=73$ \\
\hline Corporate engagement & 0.10689 & -0.87279 & 0.63952 & 0.18238 \\
\hline Social engagement & -0.40446 & 0.73940 & 0.13823 & -0.78788 \\
\hline No affective commitment & 0.41947 & -0.34123 & -0.05617 & 0.06190 \\
\hline No normative commitment & -0.49060 & -0.08015 & 0.81043 & -0.49214 \\
\hline Calculated commitment & 0.90164 & -0.10225 & -0.24560 & -0.60401 \\
\hline No social engagement & -0.22239 & 0.05976 & 0.11894 & 0.36886 \\
\hline Environmental engagement & 0.46157 & -0.05096 & 0.30826 & -0.96518 \\
\hline
\end{tabular}

We therefore see that the BPA membership is divided and comprises a mixed group of stakeholders with varying levels of engagement, or even none at all (Fig. 2).

Whereas gender and socio-professional elements do not have any significant impact on the distribution of individuals among the four groups, age appears to influence both social and corporate engagement. This result confirms former research. Bozonnet (2008) has shown that in Europe, gender has no impact on people's engagement to environmental concerns, but that age has some influence, even if the link is not very strong and not linear. He highlights that the individuals who have the strongest engagement to the environment are those between 25 and 59, whereas the youngest and the oldest have a lower commitment. These findings are in line with the results of our research. Within group 2 that corresponds to the one with the highest social engagement, members between 40 and 60 are overrepresented.

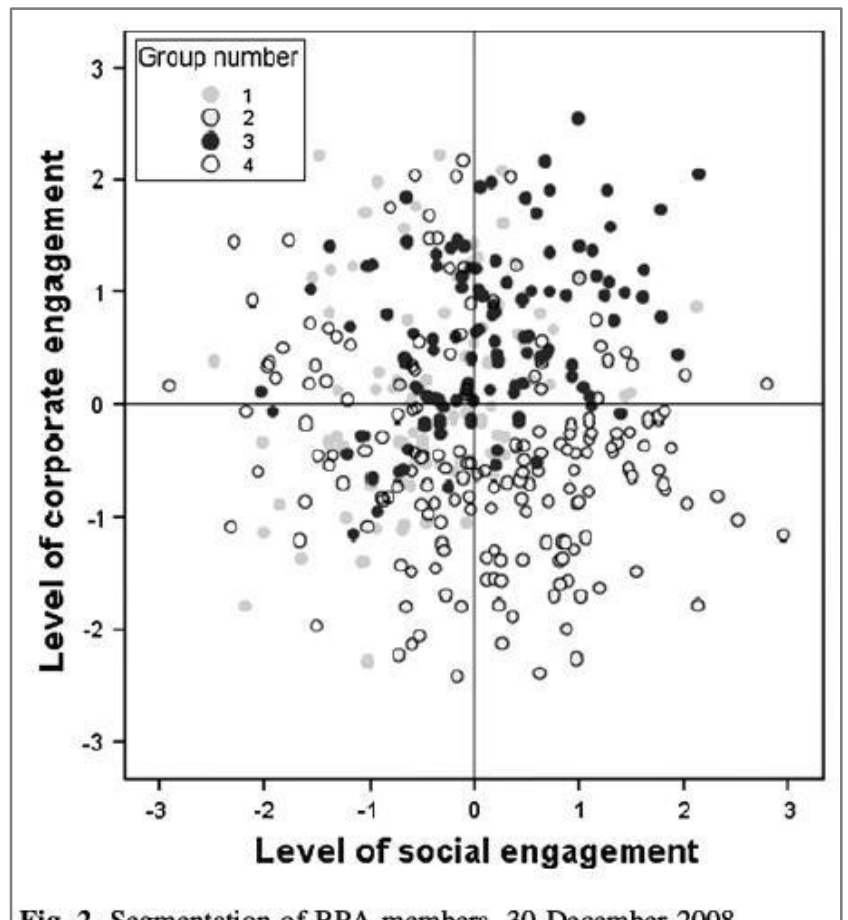

Fig. 2 Segmentation of BPA members, 30 December 2008

\section{Conclusion}

This article looks at the relations between companies and stakeholders by considering the latter as individuals. Usually research in this area analyzes stakeholders as groupings of persons supposing that the members of these groups have similar relations to the company in question. Our article instead looks at individuals to underline that they may have different relationships with the 
company. To do this, we utilize models of organizational commitment and apply them to individual stakeholders of a French mutual bank. Thus, this study lends itself to a better understanding of the diversity of members' interests and expectations, which are difficult to quantify in traditional stakeholder profiles and on which very little management research exists. Developing more knowledge in this area is particularly important in the context of the new CSR guideline ISO 26000, which imposes companies to identify their different stakeholders and to establish a dialog with them. BPA is involved in this debate, its CEO being the head of a national initiative aiming at disseminating this guideline.

This segmentation of BPA members gives the bank managers the opportunity to develop suitable communications and strategies for each group, with the goal of strengthening their corporate and social engagement, while of course maintaining overall consistency. Our model may help the bank managers develop specific communications for its militant members, socially engaged but not very involved in BPA, so as to better inform them of the different policies the bank has implemented in this area. For the allied members who are recognized for their corporate engagement to BPA without showing any particular social involvement, corporate communication could, conversely, emphasize the need for banks to be actively involved in the area of CSR and the positive economic effects of such engagement.

This empirical section of our study presents some limitations. Firstly, the two first factors corporate and social engagement account only for $31.80 \%$ of the information. The next five factors are made up of two items of corporate and social engagement. Secondly, corporate and social engagement factors do not measure all of the dimensions of capital social such as the relational and structural dimensions and de facto, this analysis does not take into account the collaborative dimension of engagement. Thirdly, the study is static and not dynamic. Further research could seek to measure corporate and social engagement over several time periods so as to highlight evolutions over time. Finally, our study only concerns one category of stakeholders. Future researches need to done to apply our model to the other categories of stakeholders within the same company and to identify the collaborative dimension of stakeholder engagement.

A revised version of our survey should be conducted regularly on the same population in order to observe any development in members' engagement, taking into account the impact of external events and the managerial practices put in place. Moreover, the survey should be carried out on other groups of stakeholders, in particular employees who are also clients and clients who are not members, to find out whether there is a similar division among these groups. This would make it possible to see whether, through applying the dynamic cloud classification method to the responses made by all the stakeholders, the groups then formed are made up of members from different stakeholder groups or if they are specific to each stakeholder group. This would indicate that the level of corporate and social engagement varies significantly between members, employees, and clients.

\section{Acknowledgments}

The authors would like to thank Ariane Berthoin Antal and Julie Bayle-Cordier for their stimulating comments. Remaining errors are, of course, the authors'. 
Section 1: 'You as a Member of Society'

Please indicate, by circling a number from 1 to 5 , how often you do the following things:

(1) Never (2) Rarely (3) Sometimes (4) Often (5) Whenever possible

1. I buy fair-trade products

$\begin{array}{lllll}1 & 2 & 3 & 4 & 5\end{array}$

2. I buy organically grown produce

$\begin{array}{lllll}1 & 2 & 3 & 4 & 5\end{array}$

3. I choose seasonal fruit and vegetables

$\begin{array}{lllll}1 & 2 & 3 & 4 & 5\end{array}$

4. I buy local produce

$\begin{array}{lllll}1 & 2 & 3 & 4 & 5\end{array}$

5. I recycle my rubbish

$\begin{array}{lllll}1 & 2 & 3 & 4 & 5\end{array}$

6. I choose public transport or car-pooling

$\begin{array}{lllll}1 & 2 & 3 & 4 & 5\end{array}$

7. I give to humanitarian, charitable or

$\begin{array}{lllll}1 & 2 & 3 & 4 & 5\end{array}$ environmental organizations

8. I am an active member of an organization $\begin{array}{llllll}1 & 2 & 3 & 4 & 5\end{array}$ or the public sphere

9. I consider social and environmental factors $11 \quad 2 \quad 3 \quad 3 \quad 4 \quad 5$ in my savings and investment choices

10. I keep up to date on sustainable development via the press, the internet and attending meetings 
Section 2: You as a Member of the Banque Populaire Atlantique Please indicate, by circling a number from 1 to 5 , to what extent you agree with the following statements:

(1) Strongly disâgree (2) Disagree (3) Indifferent (4) Agree

(5) Stronglyagree

11. I am very pleased to be a BPA member $\begin{array}{llllll}1 & 2 & 3 & 4 & 5\end{array}$

12. I enjoy talking about the BPA with my $1 \begin{array}{lllll}1 & 2 & 3 & 4 & 5\end{array}$ colleagues, friends and family

13. I feel concerned by the BPA's problems $\begin{array}{llllll}1 & 2 & 3 & 4 & 5\end{array}$

14. I could just as easily have become a $\quad \begin{array}{lllllll}1 & 2 & 3 & 4 & 5\end{array}$ member or shareholder of another bank

15. I do not feel like a member of the BPA $\begin{array}{llllll}1 & 2 & 3 & 4 & 5\end{array}$

16. I am not engaged to the BPA $\quad 1 \quad \begin{array}{lllll}1 & 3 & 4 & 5\end{array}$

17. I am loyal to the BPA because we share $1 \begin{array}{lllll}1 & 2 & 3 & 4 & 5\end{array}$ the same values

18. I am proud to tell others I am a BPA $\quad \begin{array}{lllll}1 & 2 & 3 & 4 & 5\end{array}$ member

19. I am worried about loss related to my $\quad \begin{array}{lllll}1 & 2 & 3 & 4 & 5\end{array}$ investments with the BPA

20. It would be difficult for me to leave the $\begin{array}{llllll}1 & 2 & 3 & 4 & 5\end{array}$ BPA today, even if I wanted to

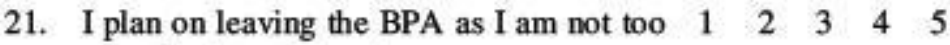
involved as a member

22. It would be too costly for me to leave the $\begin{array}{lllll}1 & 2 & 3 & 4 & 5\end{array}$ BPA today

23. I am loyal to the BPA because I have $\quad \begin{array}{lllll}1 & 2 & 3 & 4 & 5\end{array}$ invested a lot in this bank (be it economically, emotionally or socially)

24. I have never thought of leaving the BPA $1 \begin{array}{lllll}1 & 2 & 3 & 4 & 5\end{array}$ because I have not had many opportunities

25. I believe I am not under any obligation to $\begin{array}{llllll}1 & 2 & 3 & 4 & 5\end{array}$ remain a member of the BPA

26. Even to my disadvantage, I would remain $1 \begin{array}{lllll}1 & 2 & 3 & 4 & 5\end{array}$ a member of the BPA

27. I would feel guilty if I had to leave the $\begin{array}{lllll}1 & 2 & 3 & 4 & 5\end{array}$ BPA 


\section{References}

Berthoin Antal, A., \& Sobczak, A. (2004). Beyond CSR: Organizational learning for global responsibility. Journal of General Management, 30(2), 77-98.

Bevan, D., \& Werhane, P. H. (2011). Stakeholder theory. In M. Painter-Morland \& R. Ten Bos (Eds.), Business ethics and continental philosophy. Cambridge: Cambridge University Press.

Bhagat, S., Black, B., \& Blair, M. (2004). Relational investing and firm performance. Journal of Financial Research, 27(1), 1-30.

Bourdieu, P. (1980). Le capital social. Notes provisoires. Actes de la Recherche en Sciences Sociales, $31,2-3$.

Bozonnet, J.-P. (2008). Socialisation et engagement écologiste en Europe. L'école, la famille et l'environnementalisme en héritage. Congrès de l'AISLF, Istanbul, 11 juillet.

Caroll, A. B. (1989). Business \& society. Cincinnati: South Western Publishing.

Chiffet, J.-P. (2006). Que signifie avoir 60 millions de sociétaires ?. Communication at the Convention of European Cooperative banks (Convention des banques coopératives européennes), 28 March.

Donaldson, T., \& Preston, L. E. (1995). The stakeholder theory of the corporation: Concepts, evidence, and implications. Academy of Management Review, 20(1), 85-91.

Fasterling, B. (2008). A propos de l'actionnariat "détaché". Ethique et Economique, 5(2), 1-10. Freeman, R. E. (1984). Strategic management: A stakeholder approach. Boston: Pitman/Ballinger.

Freeman, R. E. (1999). Response: Divergent stakeholder theory. Academy of Management Review, 24(2), 233-236.

Freeman, R. E., \& Gilbert, D. R. (1987). Managing stakeholder relationships. In S. P. Sethi \& C. M. Falbe (Eds.), Business and society: Dimensions of conflict and cooperation (pp. 397-423). Lexington: Heath.

Freeman, R. E., \& Mc Vea, J. (2001). A stakeholder approach to strategic management. In M. Hitt, R. E. Freeman, \& J. Harrison (Eds.), Handbook of strategic management (pp. 189-207). Oxford: Blackwell Publishing.

Greenwood, M. (2007). Stakeholder engagement: Beyond the myth of corporate responsibility. Journal of Business Ethics, 74(4), 315-327.

Harrison, J. S., \& St. John, C. H. (1996). Managing and partnering with external stakeholders. Academy of Management Executive, 10(2), 46-60. Hawley, J., \& Williams, A. (2007). Universal owners: Challenges and opportunities. Corporate Governance: An International Review, 15, 415-420.

Lemoine, J.-F., \& Onnée, S. (2001). Vers une meilleure compréhension du statut d'actionnaire individuel-client. Gestion, 2000(4), 127-138.

Logsdon, J. M., \& Van Buren, H. J., III. (2009). Beyond the proxy vote: Dialogues between shareholder activists and corporations. Journal of Business Ethics, 87(1), 353-365.

Maak, T. (2007). Responsible leadership, stakeholder engagement, and the emergence of social capital. Journal of Business Ethics, 74(4), 329-343. 
MacLeod, M. R. (2009). Emerging investor networks and the construction of corporate social responsibility. Journal of Corporate Citizen, 34, 69-96.

Meyer, J. P., \& Allen, N. J. (1991). A three-component conceptualization of organizational commitment. Human Resource Management Review, 1(1), 61-89.

Meyer, J. P., \& Allen, N. J. (1997). Commitment in the workplace: Theory, research and application. Thousand Oaks: Sage.

Mitchell, R. K., Agle, B. R., \& Wood, D. J. (1997). Towards a theory of stakeholder identification and salience: Defining the principle of who and what really counts. Academy of Management Review, 22(4), 853-886.

Post, J. E., Preston, L. E., \& Sachs, S. (2002). Managing the extended enterprise: The new stakeholder view. California Management Review, 45(1), 6-28.

Richez-Battesti, N. (2006). Gouvernance coopérative et reconquête du sociétariat: une aventure inachevée ? Le cas des banques coopératives en France. In Communication at the XXIInd international conference on cooperative research.

Scholes, E., \& Clutterbuck, D. (1998). Communication with stakeholders: An integrated approach. Long Range Planning, 31(2), 227-238.

Sibieude, T., \& Vidal, R. (2008). Enjeux et perspectives du sociétariat des groupes mutualistes complexes face aux stratégies de développement à l'échelle du groupe: quelques enseignements du cas du Groupe MACIF. Working paper DR 08011, ESSEC Research Centre, Cergy. Sloan, P. (2009). Redefining stakeholder engagement. From control to collaboration. Journal of Corporate Citizen, 36, $25-40$.

Stieb, J. A. (2009). Assessing Freeman's stakeholder theory. Journal of Business Ethics, 87(3), 401414.

Thamotheram, R., \& Wildsmith, H. (2007). Increasing long-term market returns: Realising the potential of collective pension fund action. Corporate Governance: An International Review, 15, 438454.

Turker, D. (2009). How corporate social responsibility influences organizational commitment. Journal of Business Ethics, 89(2), 189-204.

Wolfe, R. A., \& Putler, D. S. (2002). How tight are the ties that bind stakeholder groups. Organization Science, 13(1), 64-80.

Wood, D. J. (1994). Business and society. New York: Harper Collins. 